\title{
Conformational protein structure shifts in aggregation prone conditions for MAb and Fab
}

Paul A. Dalby, Dept Biochemical Engineering, UCL, London UK

Antibody solution structures are critical for understanding the impact of formulation conditions upon structure and aggregation propensity. The aggregation kinetics of a Fab have been extensively mapped for $\mathrm{pH} 3.5-9$, ionic strength $0-250 \mathrm{mM}$, and at 4-65C. Synchrotron X-ray scattering (SAXS) at $23 \mathrm{C}$ reveals a $\mathrm{pH}$ - and salt-dependent conformational structure shift in one region of the protein, that correlates with aggregation propensity. Meanwhile, SAXS and constrained modelling determined that IgG4 has an asymmetric solution structure. At $\mathrm{pH} 7.4$ the relative $\mathrm{Fab}-\mathrm{Fc}-\mathrm{Fab}$ domain conformations were concentration dependent but the overall IgG4 size remained unaffected. At $\mathrm{pH} 3$, conditions significant structural changes occurred over time that preceded an increased propensity to aggregate.

References:

Chakroun N, Hilton D, Ahmad S, Platt G, Dalby P. (2016) Molecular Pharmaceutics. 13(2):307319. Mapping the aggregation kinetics of Fab. DOI: 10.1021/acs.molpharmaceut.5b00387

Abe, Y., Gor, J., Bracewell, D.G., Perkins, S.J., Dalby, P.A. (2010) Biochem. J. 432(1):101-111. Masking of the $\mathrm{Fc}$ region in human $\mathrm{IgG} 4$ by constrained X-ray scattering modelling: implications for antibody function and therapy. 